\title{
Ventilasi Mekanik pada Pengangkatan Tumor Metastasis Ekstradura Torakal dengan Teknik Anestesi Satu Paru dan Posisi Lateral Dekubitus
}

\author{
Dini Handayani Putri*), Dewi Yulianti Bisri**), Iwan Fuadi**), M. Sofyan Harahap ${ }^{* * *}$ ) \\ *Departemen Anestesiologi dan Terapi Intensif, Rumah Sakit Nasional Kanker Dharmais-Cancer Centre Jakarta, \\ ${ }^{* *}$ Departemen Anestesiologi dan Terapi Intensif Fakultas Kedokteran Universitas Padjadjaran-RSUP Hasan \\ Sadikin Bandung, ${ }^{* * * *}$ Departemen Anestesiologi dan Terapi Intensif Fakultas Kedokteran Universitas Diponegoro- \\ RSUP Dr. Kariadi Semarang
}

\begin{abstract}
Abstrak
Spinal adalah lokasi yang paling umum untuk metastasis tulang. Metastasis spine dapat menyebabkan nyeri, ketidakstabilan tulang belakang dan cedera neurologis lainnya. Pada operasi tumor spinal metastasis pendekatan pembedahan menjadi hal penting baik bagi ahli bedah saraf maupun neuroanestesi. Pada kasus ini laki-laki 60 tahun dengan tumor ekstradura metastasis torakal akan menjalani operasi pengangkatan tumor dan stabilisasi dengan pendekatan posterolateralextracavity untuk mendapat akses yang optimal ke bagian ventral spinal bagian torakal atas. Pasien di induksi dengan fentanil $200 \mathrm{mcg}$ dan propofol $100 \mathrm{mg}$, fasilitasi intubasi dengan rocuronium $50 \mathrm{mg}$ dan pemasangan double lumen tube kiri, posisi lateral dekubitus. Ketika dilakukan ventilasi satu paru pasien mengalami kejadian desaturasi oksigen sampai 93\%, dilakukan penyesuaian mode ventilator sebagai penanganannya. Pascaoperasi pasien tidak diekstubasi dan menjalani perawatan diruangan intensif selama dua hari dan dipulangkan pada hari ke 13. Tatakelola kasus ini difokuskan pada penilaian preoperatif, pengaruh posisi lateral dekubitus dan teknik anestesi satu paru terhadap fungsi respirasi dan kardiovaskular. Risiko hipoksemia akibat ketidaksesuaian ventilasi / perfusi yang menyebabkan gangguan oksigenisasi dan perfusi terhadap otak dan medulla spinalis, sehingga diperlukan tatakelola ventilasi mekanik, monitoring intraoperasi yang berhubungan dengan kaidah-kaidah neuroproteksi terhadap otak dan medulla spinalis.
\end{abstract}

Kata kunci: Anestesi satu paru; lateral dekubitus; neuroproteksi; tumor spinal

JNI 2020; 9 (1): 16-25

\section{Management of Mechanical Ventilation in the Removal of Thoracal Extradura Metastatic Tumors with One Lung Anesthesia Technique in Decubitus Lateral Position}

\begin{abstract}
The spine is the most common location for bone metastases. Spine metastases can cause pain, spinal instability and other neurological injuries. In spinal metastatic tumor surgery a surgical approach is important for both neurosurgeons and neuroanesthesiologists. In this case, a 60-year-old man with a thoracic metastatic extradura tumor would undergo tumor removal and stabilization with the posterolateralextracavity approach to obtain optimal access to the ventral spinal ventral region. Patients were induced with 200 mcg fentanyl and propofol $100 \mathrm{mg}$, facilitation of intubation with $50 \mathrm{mg}$ rocuronium and installation of the left double lumen tube, lateral decubitus position. When one lung is ventilated, the patient experiences an oxygen desaturation event of up to $93 \%$, adjusting the ventilator mode as a treatment. Postoperatively the patient was not extubated and underwent intensive care for two days and was discharged on day 13. The case management focused on preoperative assessment, the influence of lateral decubitus position and one-pulmonary anesthetic technique on respiration and cardiovascular function. The risk of hypoxemia due to ventilation / perfusion mismatches that cause oxygenisation and perfusion disorders of the brain and spinal cord, so that management of mechanical ventilation, intraoperative monitoring associated with neuroprotection rules of the brain and spinal cord.
\end{abstract}

Key words: Lateral decubitus position; neuroprotection; one - lung anesthesia technique; spinal tumor

JNI 2020; 9 (1): 16-25 


\section{Pendahuluan}

Spine adalah lokasi yang paling umum untuk metastasis pada tulang, angka kejadian metastasis spinal semakin meningkat seiring dengan harapan hidup yang lebih lama, dan perbaikan dalam perawatan medis. Metastasis spinal hadir pada $70 \%$ pasien kanker dan hingga $10 \%$ disertai kompresi pada spinal cord. Pada sebuah penelitian yang dilakukan dalam konsensus tumor spinal secara global di Eropa, menganalisis 1.477 kasus menyimpulkan bahwa $16,5 \%$ metastasis spinal dengan keterlibatan epidural berasal dari kanker payudara, $15,6 \%$ dari kanker paru-paru, 9,2\% dari kanker prostat, dan 6,5\% dari kanker ginjal; analisis 1.585 kasus metastasis tulang belakang melaporkan bahwa $70,3 \%$ berlokasi daerah torakal dan torakolumbar, $21,6 \%$ dari daerah lumbar dan sakral, sedangkan $8,1 \%$ dari daerah servikal dan servikal-torakal. Lebih dari $50 \%$ pasien dengan metastasis spinal memiliki beberapa level yang terlibat, dan 10 hingga $38 \%$ pasien memiliki beberapa segmen yang tidak bersebelahan, lokasi tumor spinal yang paling umum terletak di ekstradural. ${ }^{1,2}$ Metastasis spinal dapat menyebabkan nyeri, ketidakstabilan tulang belakang, cedera neurologis dengan kehilangan kontrol sfingter urin, rektum hingga paraplegia, namun dapat juga tidak menunjukkan gejala.

Perbaikan dalam kemoterapi, radioterapi dan terapi hormon menyebabkan peningkatkan angka harapan hidup. Seiring dengan meningkatnya kemajuan teknologi teknik bedah memungkinkan ahli bedah untuk merawat metastasis spinal lebih efektif daripada sebelumnya. Tujuan pengobatan dalam metastasis spinal adalah untuk mengoptimalkan kualitas hidup pasien dengan memberikan penghilang rasa sakit yang efektif dan mempertahankan atau memulihkan fungsi neurologis. ${ }^{1,3,4}$ Pada operasi pengangkatan dan stabilisasi tumor spinal metastasis pemilihan teknik dan pendekatan pembedahan menjadi hal penting bagi ahli bedah saraf maupun neuroanestesi. Pada kasus dengan pendekatan operasi terhadap massa tumor di daerah ventral dapat dilakukan tekhnik pembedahan berupa torakotomi dengan pendekatan postero lateralextracavity (LECA) untuk mendapatkan akses yang optimal ke bagian ventral spinal bagian torakal atas. Untuk mendapatkan akses ini pasien intraoperasi diposisikan lateral dekubitus dengan pemasangan double lumen tube untuk teknik anestesi satu paru. ${ }^{5}$ Beberapa penelitian menunjukan $40-50 \%$ pasien berisiko mengalami hipoksemia selama teknik anestesi satu paru. Ketidaksesuaian ventilasi/ perfusi, peningkatan resistensi pembuluh darah pulmonar, intrapulmonary shunt, dan peningkatan tekanan intratorakal yang dapat menghambat oksigenisasi dan perfusi otak dan medula spinalis, dimana bagian ini paling sensitif terhadap hipoksia karena kebutuhan oksigen yang tinggi, sehingga diperlukan tatakelola teknik mekanik, monitoring intraoperasi yang berhubungan dengan kaidahkaidah neuroproteksi terhadap otak dan medula spinalis serta antisipasi komplikasi pascaoperasi. ${ }^{67}$

\section{Kasus}

\section{Anamnesis}

Seorang pasien laki-laki 60 tahun dengan keluhan nyeri pada punggung bagian atas sejak 10 bulan sebelum masuk rumah sakit, keluhan disertai dengan rasa kesemutan yang menjalar serta rasa mengikat pada dada, terasa nyeri dan sesak saat menarik nafas. Kelemahan anggota gerak, gangguan defekasi dan berkemih disangkal, riwayat trauma terhadap punggung bagian atas tidak ada, riwayat demam hilang timbul tidak ada, riwayat batuk hilang timbul, batuk darah tidak ada, dari rumah sakit daerah pasien dirujuk ke RS Kanker Dharmais, dari dokter spesialis paru dilakukan pemeriksaan bronkoskopi dan CT-scan thorak didapatkan tumor pada mediastinum yang menginfiltrasi paru, dan spinal thorakal 3-4. Pasien lalu dikonsulkan ke bedah saraf direncanakan operasi pengangkatan tumor dan stabilisasi via torakotomi dengan pendekatan postero lateral extracavity (LECA).

\section{Pemeriksaan Fisik}

Pada pemeriksaan fisik, pasien tampak nyeri sedang saat menarik nafas, kontak adekuat, berat badan $60 \mathrm{~kg}$, pupil bulat isokor diameter $3 \mathrm{~mm}$, refleks cahaya baik tidak ditemukan kelaian saraf kranial. Pada pemeriksaan tanda vital, pasien 
sadar GCS 15, respirasi $17 \mathrm{kali} / \mathrm{menit}$, saturasi oksigen $97-99 \%$ dengan udara ruangan (room air) tekanan darah 120/80 mmHg, nadi 98 kali/ menit, kekuatan motorik normal baik ekstrimitas atas maupun bawah, tidak terlihat benjolan atau kelainan pada bentuk tulang belakang.

\section{Pemeriksaan Penunjang}

Pemeriksaan foto thoraks tampak konsolidasi di paratrakea kanan diameter $0,6 \mathrm{~cm}$, jantung dan aorta tidak tampak kelainan, hilus dan pleura tidak tampak kelainan, tidak tampak lesi noduler/ infiltrate parenkim paru, tidak tampak kelaianan pada iga, kesan konsolidasi di paratrakea kanan. Pemeriksaan magnetic resonance imaging (MRI) torakal dengan kontras tampak lesi fokal dengan kompresi fraktur melibatkan korpus vertebra thorakal 3 dan 4, pedikel, processus transversus, artikulasio facet dan intervetebra foramina kanan dengan kompresi pada duramater, medula spinalis sisi kanan serta infiltrasi apikal paru kanan, tidak tampak kelaianan pada korpus dan diskus vertebra torakalis, kesan metastasis korpus, pedikel, processus transversus, art facet, dan intervetebra foramina kanan disertai impresi duramater dan medula spinalis sisi kanan, infiltrasi apikal paru kanan. Pemeriksaan laboratorium sebelum operasi (tabel 1). Pasien direncanakan untuk dilakukan pengambilan massa tumor dengan pendekatan Lateral Extracavitory Approach tindakan ini dilakukan ahli bedah thorak dilanjutkan ahli bedah saraf. Pendekatan ini dipilih berdasarkan letak anatomis tumor yang berada lebih ke rongga thorak dan tidak ditemukan kelainan pada segmen posterior corpus vertebra, pendekatan ini dipilih dikarenakan memberikan keuntungan akses dan keleluasaan ahli bedah dalam pemasangan dan penempatan instrumentasi terhadap lesi yang akan dicapai selain itu tidak merusak struktur stabilistas bagian kolumna posterior dari spinal.

\section{Pengelolaan Anestesi}

Pasien masuk ke kamar operasi lalu dipasang alat monitor (tekanan darah, denyut jantung, saturasi

Tabel 1. Hasil Pemeriksaan Laboratorium Darah Pra operasi

\begin{tabular}{llll}
\hline \multicolumn{1}{c}{ Parameter } & \multicolumn{1}{c}{ Nilai } & \multicolumn{1}{c}{ Parameter } & \multicolumn{1}{c}{ Nilai } \\
\hline $\mathrm{Hb}$ & $13,4 \mathrm{gr} / \mathrm{dl}$ & Analisis Gas Darah & \\
Leukosit & $9.240 / \mathrm{mm} 3$ & $\mathrm{pH}$ & 7.459 \\
Trombosit & $402.000 \mu \mathrm{L}$ & $\mathrm{pCO}_{2}$ & 40.8 \\
Gula darah sewaktu & $140 \mathrm{mg} / \mathrm{dL}$ & $\mathrm{pO}_{2}$ & 88.4 \\
ureum & $16 \mathrm{mg} / \mathrm{dL}$ & $\mathrm{HCO}_{3}$ & 31.2 \\
Creatinine serum & $1,04 \mathrm{mg} / \mathrm{dL}$ & $\mathrm{Base}^{2}$ Excess & 8.2 \\
Natrium darah & $146 \mathrm{mEq} / \mathrm{L}$ & $\mathrm{Sa} 0_{2}$ & $97.3 \%$ \\
Kalium Darah & $4.3 \mathrm{mEq} / \mathrm{L}$ & $\mathrm{PT}$ & $12.8(\mathrm{~N}: 15.1)$ \\
Clorida Darah & $117 \mathrm{mEq} / \mathrm{L}$ & $\mathrm{aPTT}$ & $29.1(\mathrm{~N}: 27.8)$ \\
\hline
\end{tabular}
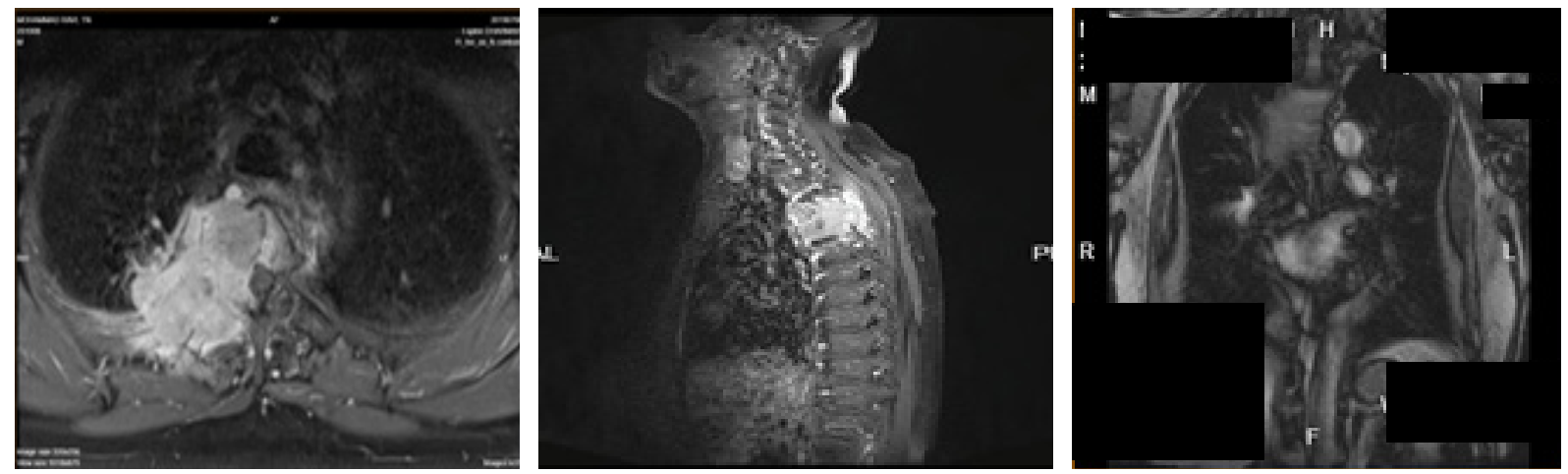

Gambar 1. MRI torakal sebelum operasi, gambar a. Potongan axial, b. Potongan sagittal, c. Potongan coronal. 
oksigen, EKG, $\mathrm{EtCO}_{2}$ dan kateter urin). Pasien di induksi dengan fentanil $200 \mathrm{mcg}$ intravena dan propofol $100 \mathrm{mg}$. Untuk fasilitasi intubasi diberikan rocuronium $50 \mathrm{mg}$, dengan pemasangan pipa endotrakea double lumen kiri no 37 Frank dengan cuff, dilakukan tes pada lumen trakea dan lumen bronkial, dengan auskultasi bunyi nafas bilateral. Setelah dipastikan sama dilakukan klem pada lumen trakea, dipastikan dari auskultasi lumen bronkial berada di paru kiri. Selanjutnya dilakukan pemasangan kateter urin Folley no 14 Frank. Sebelum posisikan lateral dekubitus, dilakukan pengecekan hemodinamik, nadi 70 kali per menit, tekanan darah $110 / 70 \mathrm{mmHg}$, saturasi oksigen $99 \%$, EtCO 2 terbaca 30, setelah dipastikan stabil pasien diposisikan lateral dekubitus. Awal operasi diberikan pemeliharaan dengan oksigen:udara= 1 liter: 1 liter, sevofluran $1-1,5 \mathrm{vol} \%$, rocuronium $10 \mathrm{mg} / \mathrm{jam}$, fentanil $50 \mathrm{mcg} / \mathrm{jam}$ mengunakan syringe pump dengan

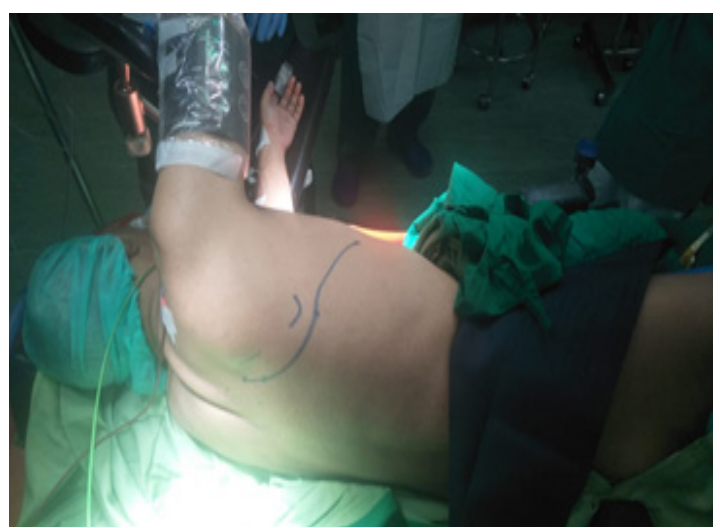

Gambar 2. Posisi intraoperasi (lateral dekubitus dengan sisi intraoperasi melalui pendekatan torakotomi dengan pendekatan postero lateralextracavity terhadap paru - paru kanan)

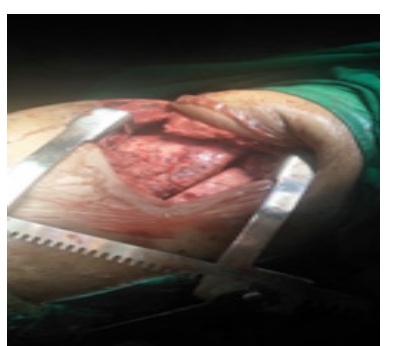

a

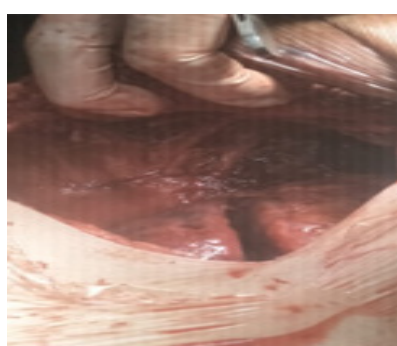

b

teknik kendali dengan mode volume kontrol, tidal volume $480 \mathrm{ml}$, frekuensi nafas $13 \mathrm{kali}$ per menit. Insisi awal dilakukan oleh dokter bedah thorak, dilakukan teknik satu paru dengan klem lumen trakeal, tampak paru kanan mulai tidak mengembang, pasien sempat mengalami desaturasi sampai 93\%, Peak inspiratory pressure (PEAK) dan main airway pressure (Paw) sempat meningkat sampai $33 \mathrm{~cm} \mathrm{H} \mathrm{O}, \mathrm{EtCO}_{2}$ meningkat 33-40, mode ventilator disesuaikan, volume tidal diturunkan menjadi $400 \mathrm{ml}$ frekuensi dinaikan menjadi 16 kali permenit, fraksi $\mathrm{O}_{2}$ menjadi 50\%, kemudian saturasi perlahan naik, 30 menit kemudian saturasi kembali nol, PEAK turun menjadi $20 \mathrm{H}_{2} \mathrm{O}$, kemudian dokter bedah thoraks membebaskan pleura dan dinding dada menempel sampai menemukan segmen posterior paru melekat terhadap tumor, tumor dibebaskan serta bagian yang menempel masuk kedalam paru dipisahkan dan diangkat, lalu operasi dilanjutkan oleh ahli bedah saraf, setelah tumor dapat dipisahkan dengan korpus dan bagian sekitarnya dilakukan pemasangan cage vertebrae, sebagai pengganti korpus vertebra 3 dan sebagian korpus vertebra 4 yang telah terdestruksi dengan bantuan $\mathrm{C}$ arm Guided. Operasi dilanjutkan kembali oleh ahli bedah thorak untuk dilakukan penutupan secara lapis demi lapis dengan pemasangan mesh. Operasi dilakukan selama 6 jam, selama operasi relatif stabil. Tekanan darah sistolik berkisar antara 140- $98 \mathrm{mmHg}$, tekanan diastolik 45-90 mmHg, laju nadi 100-60 kali/menit, saturasi oksigen 93\%-99\%, jumlah perdarahan $750 \mathrm{ml}$, jumlah cairan yang masuk $2500 \mathrm{ml}$, terdiri dari $2000 \mathrm{ml}$ kristaloid, $500 \mathrm{ml}$ koloid dan $310 \mathrm{ml}$ packed red cell (PRC), jumlah urin $1000 \mathrm{ml}$. Pada

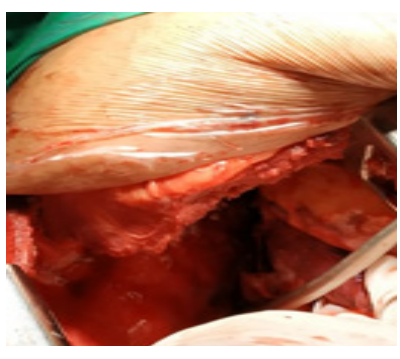

c

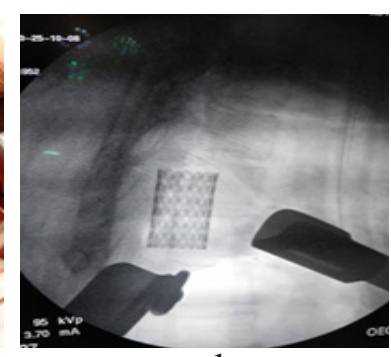

d

Gambar 3. Pendekatan Posterolateralextracavity. Gambar a. Paru paru kanan sebelum kolaps, b. Setelah kolaps dan menunjukkan tumor, c. Setelah prosesi pengangkatan tumor dan sebelum pemasangan instrumentasi, d. Konfirmasi dengan C-arm intra operasi terhadap pemasangan instrumentasi. 


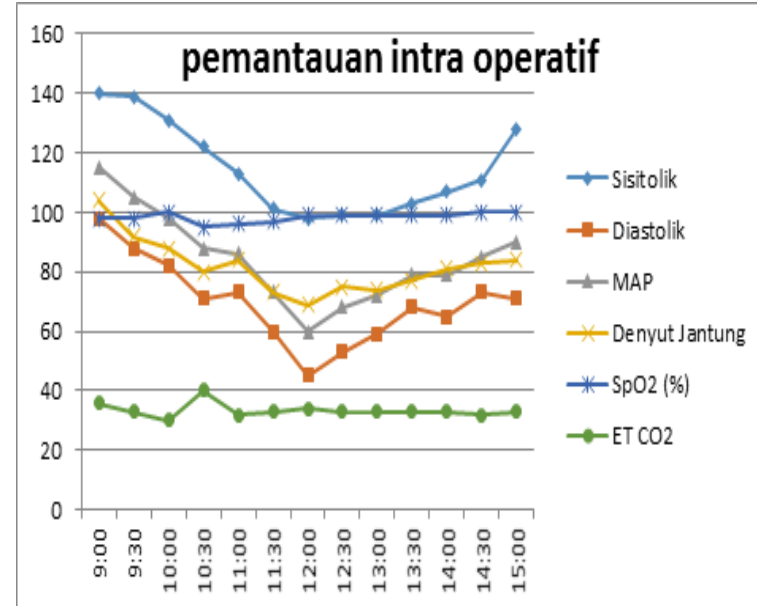

Grafik 1. Grafik Tanda Vital Intraoperasi

akhir operasi dilakukan penggantian dengan ett kinking no.7.5. Pascaoperasi diberikan analgetik fentanil $200 \mathrm{mcg}$, paracetamol $1 \mathrm{gr}$ intravena bila perlu dan ondansentron $16 \mathrm{mg}$ selama 24 jam, pasien tidak diekstubasi dirawat di ICU.

\section{Pengelolaan Pascabedah}

Hari ke 0 pascabedah pasien dirawat diruang perawatan intensif, dengan posisi kepala sedikit head up, terpasang pipa endotrakeal, dengan mode teknik mekanik PSIMV volume tidal 450 $\mathrm{mL}$, frekuensi nafas 14x/menit, PEEP 3, fraksi oksigen 50\%. Pasien tersedasi (midazolam), hemodinamik dalam batas normal, dilakukan pemeriksaan laboratorium pascaoperasi (tabel 2). Terapi: Ranitidin $2 \times 50 \mathrm{mg}$ iv, fentanil 200 $\mathrm{mcg} / 24$ jam, paracetamol 1 gr intravena bila perlu, midazolam 1mg/jam (rencana pagi dihentikan).Hari ke 1 pascabedah, pasien sadar dengan ventilator minimal mode spontan PS 6, PEEP 5, fraksi oksigen 30\% dengan frekuensi nafas 14-18 kali/menit. tekanan darah 120/69

Tabel 2. Hasil Pemeriksaan Laboratorium Darah Pascaoperasi

\begin{tabular}{llllll}
\hline \multicolumn{1}{c}{ Parameter } & \multicolumn{2}{c}{ Nilai } & \multicolumn{2}{c}{ Parameter } & \multicolumn{2}{c}{ Nilai } \\
\hline & Hari 1 & Hari 2 & & Hari 1 & Hari 2 \\
$\mathrm{Hb}$ & $10.5 \mathrm{gr} / \mathrm{dl}$ & & Analisis Gas Darah: & \\
Hematokrit & $30.1 \%$ & & $\mathrm{pH}$ & 7.34 & \\
Leukosit & $17.000 / \mathrm{mm} 3$ & & $\mathrm{pCO}_{2}$ & 39 & 36 \\
Trombosit & $315.000 \mu \mathrm{L}$ & & $\mathrm{pO}_{2}$ & 110 & 120 \\
Gula darah sewaktu & $170 \mathrm{mg} / \mathrm{dL}$ & & $\mathrm{HC}_{3}$ & & \\
Natrium darah & $135 \mathrm{mEq} /$ & $135 \mathrm{mEq} / \mathrm{L}$ & $\mathrm{Base}^{2}$ Excess & & \\
Kalium Darah & $3.4 \mathrm{mEq} / \mathrm{L}$ & $3.5 \mathrm{mEq} / \mathrm{L}$ & $\mathrm{Sa}_{2}$ & $98.4 \%$ & $99.1 \%$ \\
Clorida Darah & $100 \mathrm{mEq} / \mathrm{L}$ & $101 \mathrm{mEq} / \mathrm{L}$ & & & \\
\hline
\end{tabular}

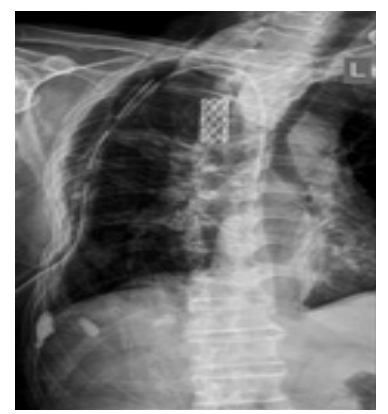

a

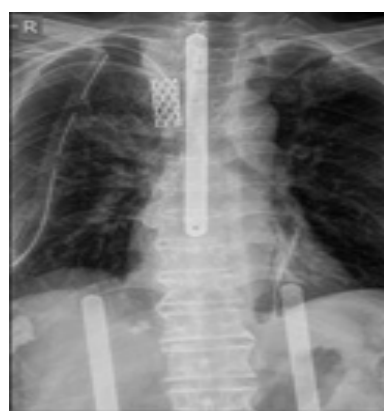

b
Gambar 4. Foto polos thoraks pascaoperasi.

Gambar a. Tampak bayangan gambar instrumentasi yang telah dipasang dengan kedua paru dalam kondisi baik tanpa komplikasi. Gambar b. Posisi AP dengan korset
$\mathrm{mmHg}$, nadi 88x/menit, saturasi $\mathrm{O}_{2}$ 99\%, kekuatan motorik normal, CRT normal, pupil bulat isokor $3 / 3$, reflek cahaya $+/+$, produksi urin $100 \mathrm{~mL} / \mathrm{jam}$, produksi WSD $250 \mathrm{ml} / 24$ jam serous hemoragik. Tambahan terapi metronidazole $3 \mathrm{x}$ $500 \mathrm{mg}$ iv, rencana ekstubasi bila stabil. Hari ke 2 pascabedah, pasien sadar dengan nasal kanul 3 Liter/menit, dengan frekuensi nafas 15-18 kali/menit, tekanan darah 110/70 $\mathrm{mmHg}$, nadi 89x/menit, saturasi $\mathrm{O}_{2} 98 \%$, nyeri saat bernafas berkurang, produksi WSD $100 \mathrm{ml} / 24$ jam serous, kekuatan motorik normal, dan dilakukan pemeriksaan laboratorium darah (tabel 2). Hari ke 3 pasien pindah keruang rawat biasa. 


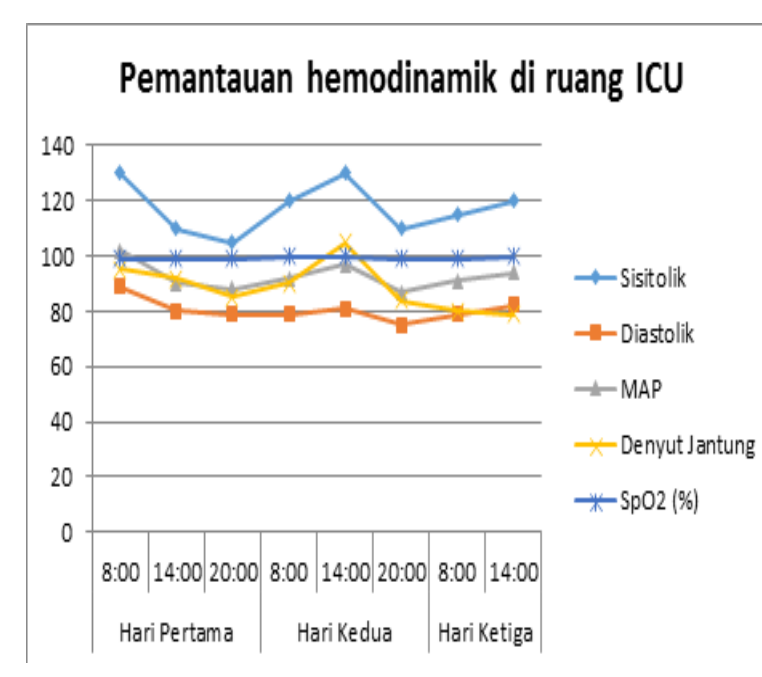

Grafik 2. Tanda-Tanda Hemodinamik di ruang ICU

\section{Pembahasan}

Tatakelola anestesi pada kasus ini dimulai dengan melakukan penilaian preoperatif yang rutin dilakukan untuk mencari komorbid yang dapat menjadi risiko saat operasi. Penilaian dilakukan terutama pada fungsi kardiorespirasi. Gejala umum seperti produksi dahak yang berlebihan, sesak nafas dan batuk menandakan ada iritasi bronkus dan sekresi jalan nafas. Merokok merupakan faktor resiko yang biasanya ada pada pasien yang akan menjalani torakotomi, penghentian merokok harus dilakukan sedikitnya 48 jam sebelum operasi. Tindakan ini akan menurunkan karboksihemoglobin dan mempercepat pemulihan pascaoperasi. ${ }^{8,9}$

Gangguan pada sistem kardiovaskular seperti disritmia, disfungsi ventrikel, hipotensi, gangguan fungsi pernafasan karena paralisis otot nafas dan tumor primer yang berasal dari paruparu merupakan perhatian khusus untuk dapat melakukan teknik anestesi paru fungsi paru yang baik diperlukan untuk kompensasi teknik anestesi satu paru. Selain itu dilakukan penilaian defisit neurologis seperti kelemahan anggota gerak, gangguan fungsi sensorik, gangguan fungsi kandung kemih, ileus pada sistem pencernaan., Pada kasus ini walaupun tumor berasal dari paruparu secara klinis dan pemeriksaan laboratorium darah normal, tidak ditemukan gangguan fungsi motorik, fungsijantung dan fungsi paruyang cukup baik, hanya ditemukan rasa nyeri saat menarik nafas. Teknik anestesi dan obat anestesi yang dipilih berdasarkan kondisi pasien dan adanya komorbid. Selain itu pertimbangan penggunaan neuromonitoring dapat mempengaruhi teknik anestesi yang digunakan, namun pada kasus ini tidak dilakukan. Beberapa kaidah menyangkut risiko cedera akibat posisi lateral dekubitus harus diperhatikan seperti, kepala pasien harus dalam posisi netral, untuk menghindarkan rotasi leher yang berlebihan, kedua mata ditutup untuk menghindari komplikasi okular seperti abrasi kornea, untuk menghindari cedera pada pleksus brakialis sebaiknya digunakan penyangga pada aksila dependen, padding harus ditempatkan di antara kaki untuk mencegah kerusakan saraf peroneum dan saphenous. ${ }^{10}$

Posisi lateral dekubitus dan teknik anestesi satu paru memberikan tantangan signifikan pada kesesuaian ventilasi dan perfusi (V/Q), karena Pertukaran gas yang efisien bergantung pada kesesuaian V/Q. Pasien cenderung mengalami gangguan kesesuaian $\mathrm{V} / \mathrm{Q}$ akibat posisi lateral dekubitus, induksi anestesi, teknik mekanik, pemakaian pelumpuh otot dan terbukanya dinding dada. Pada pasien sadar yang mengalami perubahan posisi dari supine ke posisi lateral dukubitus akan terjadi perubahan dimana tekanan gravitasi akan meningkatkan aliran darah ke paru dependen (bawah), teknik spontan juga akan meningkatkan aliran gas paru dependen sehingga kesesuaian $\mathrm{V} / \mathrm{Q}$ dapat dipelihara tetap normal. Bila paru kanan sebagai paru nondependen (atas), ia akan mendapatkan 45\% dari aliran darah total, sedangkan pada keadaan supine paru kanan mendapat 55\%. Bila paru kiri sebagai paru nondependen, ia akan mendapatkan 35\% dari aliran darah total, sedangkan pada keadaan supine ia mendapatkan 45\%. Bila kedua distribusi aliran darah ini dikombinasikan (paru kanan dan paru kiri sebagai paru nondependen untuk jangka waktu yang sama), distribusi aliran darah pada posisi lateral dekubitus dengan teknik dua paru menjadi $40 \%$ ke paru nondependen dan $60 \%$ ke paru dependen. ${ }^{11}$ Induksi anestesi, posisi dekubitus lateral, paralisis atau kelumpuhan otot, dan teknik mekanis akan mengakibatkan gangguan progresif dari kesesuaian V/Q. Setelah isolasi paru- 
paru, sisa oksigen yang terbentuk akan secara bertahap diserap dari paru tanpa teknik, terjadi penyerapan lengkap sampai atelektasis. Pada titik itu, aliran darah paru-paru yang menuju ke paruparu daerah operasi sepenuhnya mengandung perfusi yang terbuang. Pirau (shunt) kanan-kekiri yang dihasilkan oleh paru-paru tanpa teknik menambah dari shunt normal yang terjadi di paru-paru. Karena aliran darah jantung ke setiap paru kira-kira sama (paru kanan 55\%, paru-paru kiri $45 \%$, hal ini secara matematis memberikan hasil dalam fraksi shunt setidaknya 50\%. Baik mekanisme aktif dan pasif akan menurunkan aliran darah menuju daerah paru-paru yang dioperasi. Pada posisi lateral, manipulasi bedah dan gravitasi secara pasif akan mengurangi aliran darah ke paru - paru tanpa teknik, yang dapat dilihat pada gambar 5 dibawah ini. Selain itu, hipoxic pulomany vasoconstriction (HPV) secara aktif akan meningkatkan resistensi pembuluh darah di paru tanpa teknik, dan menghasilkan penurunan fraksi shunt secara bertahap sehingga pada umumnya dapat ditoleransi, namun dari beberapa penelitian menunjukan $40-50 \%$ pasien tetap berisiko mengalami hipoksemia selama anestesi dengan satu paru. ${ }^{11}$

Berdasarkan skematis gambar diatas (gambar 5), selama pembedahan saat rongga dada dibuka, akan menyebabkan kehilangan tekanan negatif intrapleural yang menyebabkan beban mediastinum menekan paru dependen, yang semakin memperburuk tingkat kesesuaian antara ventilasi dan perfusi. Di sisi lain paru nondependen akan bebas bergerak, kemudian paru nondependen diisolasi, pergerakan yang dilakukan oleh ahli bedah terhadap paru nondependen akan tetap dibatasi berdasarkan regangan maksimal terhadap parenkim paru, untuk mencegah cedera pada parenkim paru. Distribusi aliran darah paru tidak akan terpengaruh dengan membuka dada kecuali bila ada distorsi atau gangguan pada struktur mediastinum, isolasi paru non dependen akan memaksa ventilasi ke paru dependen sehingga mengembalikan kesesuaian ventilasi dan perfusi. ${ }^{11}$ Ventilator selama anestesi satu paru dalam kasus ini, bertujuan mempertahankan oksigenisasi yang baik, terhadap paru dan organ penting lainnya terutama otak dan medulla spinalis sebagai neuroproteksi. Langkah langkah tatakelola ventilator selama anestesi satu paru tersebut dapat dilihat dalam tabel berikut (tabel 1). ${ }^{12,13}$ Strategi tatakelola ventilator dalam anestesi satu paru: menghindari pemberian $\mathrm{FiO}_{2}$ tinggi diawal, proteksi teknik selama intraoperasi, tidal volume yang rendah (TV) 5-6 $\mathrm{mL} / \mathrm{kg}$, pemberian PEEP pada paru dependen (5-10 $\mathrm{cm} \mathrm{H}_{2} \mathrm{O}$ ), recruitment manuver, pemberian CPAP pada paru non dependen, menjaga driving pressure tetap rendah pada ventilator. Pemberian $\mathrm{FiO}_{2} 100 \%$ diawal akan menyebabkan ateletaksis dan kesulitan recruitment manuver, disebabkan pengambilan tempat nitrogen yang menyebabkan alveoli kolaps, sebaiknya $\mathrm{FiO}_{2}$ diawali serendah mungkin, bila diperlukan baru ditingkatkan. ${ }^{6,12,13}$

Roteksi teknik intraoperasi meliputi 3 komponen, low tidal volume (TV) $5-6 \mathrm{~mL} / \mathrm{kg}$, dari beberapa penelitian pemberian TV $10 \mathrm{ml} / \mathrm{kg}$ pada satu paru dapat menginduksi respon inflamasi dan risiko gagal nafas pascaoperasi. Pemberian PEEP pada paru dependen $5-10 \mathrm{~cm} \mathrm{H}_{2} \mathrm{O}$, bertujuan meningkatkan functional residual capacity, dan meningkatkan kesesuaikan V/Q pada paru dependen dan mencegah alveoli kolaps di akhir ekspirasi, namun level PEEP tidak melebihi pemberian continuous positive airway pressure (CPAP) untuk mencegah pengalihan aliran darah ke paru non dependen. Pada kasus bedah saraf penggunaan PEEP sendiri masih kontroversi, karena dapat mengingkatkan risiko peningkatan tekanan intrakranial (TIK), namun dari beberapa literatur mengatakan pemberian PEEP dapat dilakukan dengan aman tanpa risiko peningkatan TIK selama besarnya PEEP tidak melebihi TIK.

Recruitment manuver dengan menggunakan PEEP dapat membuka kembali paru yang ateletaksis untuk meningkatkan oksigenisasi. ${ }^{6}, 12,13$ Pemberian CPAP pada paru nondependen $5 \mathrm{~cm}$ $\mathrm{H}_{2} \mathrm{O}$ tidak mengganggu akses pembedahan, pemberian CPAP dapat menurunkan respon imun selama anestesi satu paru yang meningkatkan risiko acute lung injury dan meningkatkan $\mathrm{PaO}_{2}$ selama anestesi satu paru. ${ }^{6,12,13}$ Untuk mode ventilator dari beberapa penelitian tidak ditemukan perbedaan signifikan antara penggunaan mode pressure support dan volume 
support, yang terpenting tetap menjaga driving pressure tetap rendah, namun bila intraoperasi terjadi peningkatan tekanan jalan nafas (PAW), pressure support dapat menjadi pilihan untuk mencegah barotrauma, peningkatan PAW $>45 \mathrm{~cm}$ $\mathrm{H}_{2} \mathrm{O}$ dihubungkan dengan resiko pnemothoraks dan penurunan aliran vena ke jantung yang menyebabkan resiko peningkatan tekanan intrkranial dan intramedula yang meningkatkan resiko perdarahan intraoperasi. ${ }^{6,12,13}$

Pada kasus ini dilakukan penyesuaian mode ventilator saat teknik satu paru, dilakukan penurunan VT menjadi $6 \mathrm{~mL} / \mathrm{kg}$, frekuensi nafas menjadi 16 kali/menit, $\mathrm{FiO}_{2}$ dinaikan menjadi $50 \%$, diberikan PEEP $5 \mathrm{~cm} \mathrm{H}_{2} \mathrm{O}$, dengan mode ini saturasi oksigen dapat dipertahankan, $\mathrm{EtCO}_{2}$ kembali dalam batas normal, dan PAW kembali normal selama operasi.

Hipoksia selalu menjadi perhatian utama selama anetesi satu paru. Penelitian sebelumnya menunjukkan bahwa $40-50 \%$ pasien akan menderita hipoksemia selama anestesi satu paru. Faktor-faktor Prediktor untuk kemungkinan terjadinya desaturasi telah diidentifikasi. Pada sebuah penelitian yang dilakukan untuk menentukan faktor prediksi terhadap hipoksia selama anestesi satu paru, menemukan bahwa jumlah perfusi sebelum operasi dan teknik ke paru - paru yang dioperasi berkorelasi terbalik dengan $\mathrm{PaO}_{2}$ setelah 10 menit anestesi satu paru. Seperti halnya HPV yang hanya mampu membagi dua aliran darah melalui paru - paru yang dioperasi selama teknik satu paru, menyimpulkan bahwa tingkat aliran darah pra operasi ke paru yang akan dioperasi dapat membantu memprediksi jumlah shunting intraoperasi. ${ }^{13}$ Pada penelitian lain yang juga untuk memprediksi faktor-faktor penyebab hipoksia dalam anestesi satu paru, menunjukkan bahwa $\mathrm{PaO}_{2}$ selama anestesi satu paru berhubungan dengan banyak faktor. Oksigenasi yang buruk selama teknik dua paru bersifat prediktif dari kesulitan oksigenasi yang berkelanjutan seperti halnya operasi pada sisi kanan (karena peningkatan perfusi ke sisi itu). Fungsi paru pra operasi (FEV1) sebagai tanda prediktif oksigenasi yang buruk saat anestesi satu paru, disebabkan oleh kurangnya auto-PEEP dan usaha pengembalian fungsi (de-recruitment) sekunder paru-paru normal. ${ }^{13}$ Pada kasus ini pasien menjalani teknik satu paru selama kurang lebih 120 menit, diawal terjadi episode desaturasi sampai $93 \%$, kebanyakan desaturasi dapat ditolerir sampai $90 \%$, namun batas ini berbeda pada pasien-pasien dengan komorbid cerebrovascular disesase, anemia dan penyakit arteri koronaria. Selama operasi dilakukan pemantau $\mathrm{EtCO}_{2}$ di monitor namun tidak dilakukan pemeriksaan laboratorium darah, selama anestesi satu paru sebaiknya dilakukan pemeriksaan $\mathrm{PaCO}_{2}$, dan $\mathrm{PaO}_{2}$ untuk mendeteksi hiperkarbi dan hipoksemia intraoperasi, tidak ada rekomendasi maksimal dari nilai $\mathrm{PaCO}_{2}$ yang perbolehkan, intraoperasi $\mathrm{PCO}_{2}$ diharapkan 35-40, sedangkan penurunan $\mathrm{PaO}_{2}<60$ dapat menyebabkan iskemi pada otak dan medulla spinalis, dapat pula meningkatkan resiko defisit neurologis pascaoperasi. Sebuah penelitian menyatakan selama anestesi satu paru $\mathrm{EtCO}_{2}$ merupakan parameter yang dapat diandalkan dalam mempredikisi $\mathrm{PaCO}_{2}$, Namun, ketika waktu operasi cukup panjang $\mathrm{PaCO}_{2}$ arteri mungkin lebih dapat diandalkan daripada $\mathrm{ETCO}_{2}$, seperti pada kasus ini sebaiknya introperasi dilakukan pemeriksaan AGD berkala, tidak hanya mengandalkan $\mathrm{ETCO}_{2}$ yang terdapat di monitor mesin anestesi. ${ }^{14}$

Selama anestesi satu paru, untuk mendeteksi hipoksia dan episode desaturasi otak sebenarnya tidak cukup dengan oksimetri standar. Pada sebuah penelitian menyelidiki kejadian dan faktor risiko untuk desaturasi otak dengan memantau oksigenasi otak $\left(\mathrm{rSO}_{2}\right)$ dengan menggunakan alat bantu near infrared spectroscopy/spektroskopi inframerah berjarak dekat (NIRS) dengan pasien yang membutuhkan anestesi satu paru. ${ }^{15}$ Delapan dari 40 pasien, ditemukan penurunan $\mathrm{rSO}_{2}$ yang berkepanjangan kurang dari $75 \%$ dari nilai dasar, yang dicatat $25 \%$ dari durasi anestesi satu paru. Delapan pasien ini berusia lebih tua, memiliki obesitas dan lebih cenderung menjadi ASA III daripada pasien lainnya. Karena tidak ada perbedaan yang signifikan di latar belakang pasien atau nilai pemantauan lainnya, penulis menyimpulkan bahwa pemantauan menggunakan NIRS mungkin bermanfaat mendeteksi desaturasi otak dan memungkinkan intervensi dini pada pasien selama anestesi satu paru. parameter ini 
lebih bersifat superior dalam memantau kadar oksigen ke otak dibandingkan dengan pulse oksimetri standar. ${ }^{16}$ Pemantauan saturasi oksigen otak menjadi semakin penting dalam operasi dengan teknik anestesi satu paru.

Kejadian desaturasi oksigen otak yang signifikan dapat meningkatkan resiko gangguan fungsi kognitif pascaoperasi. Penyebab desaturasi otak pada teknik anestesi satu paru lebih terkait dengan hipoksemia perioperatif daripada penurunan hemodinamik. Pada sebuah penelitian ditemukan hubungan antara penurunan fungsi kognitif terhadap kondisi hipoksia pascaanestesi satu paru, yang dibuktikan dengan tes fungsi kognitif berupa Mini-Mental Status Exam. MiniMental Status Exam (MMSE) dapat digunakan untuk mengidentifikasi demensia subklinis perioperatif yang akan menjadi faktor risiko pada anestesi satu paru, oleh karena itu pada pasien bedah saraf dengan tindakan pembiusan anestesi satu paru sebaiknya dilakukan test MMSE untuk mendeteksi adanya disfungsi kognitif pasca operasi (POCD). ${ }^{17,18}$ Pascaoperasi pasien tidak langsung di ektubasi, dilakukan penggantian double lumen dengan endotrakeal tube biasa sebelum pasien ditransportasi ke ICU, hal ini terkait dengan beberapa komplikasi yang dapat terjadi dari pasca teknik anestesi satu paru. Lama durasi anestesi satu paru intraoperasi $>100$ menit dapat meningkatkan resiko acute lung injury pascaoperasi, laserasi paru dapat terjadi selama diseksi, perlengketan pada pleura atau dari trauma langsung dengan instrumen, sehingga meningkatkan risiko pneumotoraks pascaoperasi. Tanda-tanda tension pneumotoraks seperti sesak nafas, hipoksemia, penurunan bunyi paru unilateral, deviasi trakea, distensi vena jugular, hipotensi, dan takikardia harus diwaspadai pascaoperasi. Komplikasi perdarahan dapat terjadi pascaoperasi, chest tube harus ditempatkan di lokasi akumulasi perdarahan, tersering di area posterior di daerah paraspinous, harus tetap di tempatnya sampai produksi drain menurun. Jika pascaoperasi produksi drain terus meningkat, maka pertimbangan untuk torakotomi ulangan dan hemostasis langsung harus diberikan. Cedera duktus toraksikus dapat dijumpai, chylothorax diidentifikasi dengan rontgen dada, dikombinasikan dengan produksi cairan seperti susu dari chest tube. Perawatan mungkin melibatkan nutrisi parenteral dengan drainase chest tube lanjutan. Thorakosintesis atau torakotomi ulang untuk perbaikan lebih lanjut kelanjutan produksi chyle. ${ }^{5}$ Infeksi pascaoperasi dapat menyebabkan abses pleura. Jika pada awal perkembangan, drainase chest tube dengan intravena antibiotik biasanya berhasil mengobati proses tersebut. Tahap akhir abses pleura mungkin memerlukan torakotomi untuk dekortikasi dan evakuasi. ${ }^{5}$ Pada pasien ini terpasang chest tube sampai dengan 10 hari perawatan, dengan produksi cukup banyak, namun secara umum pasien stabil dapat diekstubasi hari kedua, pindah ke ruang rawat biasa dan pulang pada hari ke 13 perawatan.

\section{Simpulan}

Seorang neuroanestesi harus memahami perubahan fisiologi akibat teknik anestesi satu paru, tatakelola ventilasi mekanik untuk mencegah risiko hipoksia dan peningkatan tekanan jalan nafas yang menyebabkan peningkatan tekanan intrakranial dan intramedula. Untuk monitoring intraoperasi, selain parameter standar seperti pulse oksimetri, $\mathrm{EtCO}_{2}$, dan analisa gas darah, pemantauan menggunakan NIRS mungkin bermanfaat dan lebih superior dalam mendeteksi desaturasi otak, yang memungkinkan intervensi dini pada pasien selama anestesi satu paru yang berhubungan dengan kaidah-kaidah neuroproteksi terhadap otak dan medula spinalis untuk keluaran pasien yang lebih baik.

\section{Daftar Pustaka}

1. Choi D, Crockard A, Bunger C, Harms J, Kawahara N, Mazel C, Melcher R. Review of metastatic spine tumour classification and indications for surgery: the consencus statement of the Global Spine Tumour Study Group. Eur Spine J 2010;19:215-22.

2. Maccauro G, Spinelli S, Mouro S, Perisano C, Graci C, Rosa A. Physiopathology of spine metastasis. Int J Surg Oncol 2011; 1-7. 
3. Lee S, Jung H. Metastatic spinal tumor. Asian Spine J 2012;6:71-87

4. Arnatouvic K, Arnatouvic A. Extramedullary intradural spinal tumors: a review of modern diagnostic and treatment options and a report of a series. Bosn J Basic Med Sci 2001; 40-5.

5. Mark E, Christopher M, Michael S, James S. Transthoracic and transabdominal approaches to the spine. Dalam: Kumar M, Levine J, Schuster J, Kofke A, eds. Neurocritical Care Management of Neurosurgical Patient. Philadelphia: Elsevier; 2018, 333-42.

6. Senturk M, Slinger P, Cohen E. Intraoperative mechanical ventilation strategies for one - lung ventilation. Dalam: Best Practice \& Research Clinical Anaesthesiology. Philadelphia: Elsevier; 2015; 29(3): 357-69.

7. Stiler G, Asgarzadie F, Cole D. Neurosurgical disease and trauma of spine and spinal cord: anesthetic consideration. Dalam: Cottrell JE, Smith D, eds. Anesthesia and Neurosurgery, 4th ed. Philadelphia: Elsevier; 2001, 351-98.

8. Lubelski D, Steinmetz MP. Lateral extracavitary approach. Dalam: Benzel's Spine Surgery Techniques, Complication Avoidance, and Management. 4th ed. Philadelphia: Elsevier; 2017, 424-8.

9. Stacie D. Anesthesia for intramedullary spinal cord tumors. Dalam: Mongan PD, Soriano SG, Sloan TB, eds A practical approach to neuroanesthesia. 1st ed. Philadelphia: Lippincott William \& Wilkins, 2013; 192-9.

10. Chanhung Z, McDermot M. Surgical positioning. Dalam: Gupta A, Gelb A, Duane D. eds. Essentials of neuroanesthesia and neurointensive care. 2nd ed. United Kingdom: Cambride University Press, 2018, 99-107.
11. Lohser J, Ishikawa S. Physiology of the lateral decubitus position, open chest and one-lung ventilation, Dalam : Principles and Practice of Anesthesia for Thoracic Surgery. Slinger P. New York : Springer, 2011, 71-82.

12. Kozian A, Schiling T. Protective ventilatory approach to one lung ventilation: more than reduction of tidal volume. Curr Anesthesiol Rep. 2014; 150-9.

13. Lohser J, Ishikawa S. Clinical management of one lung ventilation. Dalam: Slinger P. Principles and Practice of Anesthesia for Thoracic Surgery. New York: Springer, 2011, 83-101.

14. Lee JS, Han JU, Shun CS, Lim KH. Does endtidal $\mathrm{PCO}_{2}$ reflect adequatly arterial $\mathrm{PCO}_{2}$ during one-lung ventilation for thoracoscopy. Korean J Anestheisol 1996; 31(4); 466-71 .

15. Tobias JD, Johnson GA, Rehman S, Fisher R, Caron N. Cerebral oxygenation monitoring using near imfrared spectroscopy during onelung ventilation in adults. J Minim Access Surg. 2008;4(4): 104-7.

16. Li XM, Li F, Liu ZK, Shao MT. Investigation of one lung ventilation post operative congitive dysfunction and regional cerebral oxygen saturation relations. J.Clin. Anesthesiol 2013; 29 (1): 53-6.

17. Sungur F, Arslantas MK, Ayanoglu AO. Effects of cerebral oxygen desaturation during one lung ventilation on postoperative cognitive function as assessed by cerebral oximetry: a prospective, observational study. J Clin Anesth Manag. 2016 May 1(3): 1-6.

18. Bisri DY, Bisri T. Pencegahan dan pengobatan disfungsi kognitif setelah cedera otak traumatik. Jurnal Neuroanestesi Indonesia, 2014;3 (1): 37-47. 